\title{
The reinterpretation of histories in identities of newly established regions: The case of Local Action Groups in Czechia
}

\author{
Michal SEMIAN ${ }^{1}$ and Aleš NOV ÁČEK ${ }^{2}$
}

\begin{abstract}
History is a construct based on the reselection, reconstruction and reinterpretation of past events in order to validate former, present, as well as future actions of actors. Therefore, there is no single history but rather many histories based on different ways of reinterpretation. The reinterpretation of history plays an important role in the process of regional identity formation. In this paper we aim to examine how and to what extent the relatively new ad hoc regions - Local Action Groups (LAGs) - in Czechia use history and historical and historicizing elements to present the region's image, and how LAGs reinterpret history in order to foster a sense of territorial togetherness among inhabitants. The research had two phases. In the first phase, we evaluated the primary presentation of all 180 LAGs. While in the second one, more detailed analysis was performed on the strategies of selected LAGs towards the reinterpretation of history. In general, we can conclude that LAGs work with history and historical themes only to a limited extent. However, some LAGs use actively history. The paper identifies three ways of reinterpretation of history engaged in the process of regional identity formation: regional patriotic, critical and conciliatory.
\end{abstract}

Keywords: regional history, new regionalism, regional identity, reinterpretation of history, Local Action Group, Czechia

\section{Introduction}

Since the early 1990s, regionalism has swiftly redeveloped in Europe. It is characterized by the rapid growth of new ad hoc regions. In Czechia, this boom could primarily be observed in the new millenium in connection with the country's EU accession. In order to prevent the newly created regions from becoming mere ephemeral initiatives, they must defend their position in the regional system by building up their image and strengthening their inhabitants' sense of regional togetherness (SEmian, $M$. 2016a). The region's image and the inhabitants' regional consciousness are the two basic, mutually connected elements of regional identity, according to PAAsI, A. (1986). The construction of a regional identity, therefore, is necessary for the region's further reproduction and its embeddedness in the regional system.
Regional identity is a specific type of territorial identity with collective character. Regional identity is produced and reproduced within the discourse of social practices and power relations (PAAsI, A. 2013). It is a self-standing phenomenon incorporating human perception, attachment, and even regional politics. Most often it is negotiated within the duality between "us" and "the others" (see e.g. Massey, D. and Jess, P. 1995; Crang, M.A. 1998; Semian, M. 2016b). In the context of the new regionalism, regional identity is understood as a catalyst for regional economic development and a tool in the hands of regional actors (KeAting, M. 1998; TOMANEY, J. and WARD, N. 2000).

As mentioned above, regional identity can be deconstructed into two mutually intertwined parts: on the one hand, regional identity is viewed through the prism of identifica-

\footnotetext{
${ }^{1}$ Department of Social Geography and Regional Development, Faculty of Science, Charles University in Prague. Albertov 6, 12843 Prague 2. Czechia. E-mail: semian@natur.cuni.cz

${ }^{2}$ Department of Geography, Faculty of Education, University of South Bohemia in České Budějovice, Jeronýmova 200/10, 37115 České Budějovice, Czechia, E-mail: anovacek@pf.jcu.cz
} 
tion. It can be described as the "regional consciousness of inhabitants." On the other hand, it is addressed through the prism of the created, mediated, and perceived "identity (image) of region" (PAAsI, A. 1986). The regional consciousness of inhabitants is socially constructed, nevertheless, any human choice is influenced through heritage (KuČERA, Z. et al. 2008) and the process of socialization. Identity is, thus, an ancestral phenomenon (GIDDENS, A. 1991), while the identity of a region is discussed as a constructed image both inside and outside of the region. Regional images can be (re)produced by the general public based on their knowledge and perception of available information (PAAsI, A. 1986). Nonetheless, they are primarily (re)produced by various actors in order to attract the regional consciousness and to pursuit their own particular goals (Semian, M. 2012). During this process, various regional components ranging from society and its economic activity through natural and cultural heritage and landscape features to historical heritage, including the history of the region itself as well as the history that takes place in the territory, are reinterpreted, commodified, and exploited.

Thus, history and historical events have an important role in the process of regional identity formation. They can become a symbol that the inhabitants might feel attached to (a link to the roots). They can be commodified and used as a tool to promote identification with a particular territory. They can be reinterpreted to support the idea of the region's long sociospatial continuity of existence. Nevertheless, one must always bear in mind that history is the contemporary interpretation of past evidence for future action (RIUKuLEHTo, S. 2015); it is a construct, written by winners, and it is presented and promoted to validate their former, present, as well as future actions. Thus, history is relative and is under the influence of the power relations in the area. For more ideas on the various perception of history see e.g. Tosh, J. 2015; or in the Czech context ŠUbrT, J. and VinOPAL, J. 2013.

In the regional identity formation process, history is selected, generalized, and reinterpret- ed by regional actors according to their goals. Thus, both tangible and intangible heritage is rearticulated, and historical images of the region are constructed and mediated in the form of narratives, events, periods, sites, symbols, etc. And, of course, the present image, symbols (name, values, borders, etc.) are retrospectively projected onto previous eras to strengthen the contemporary idea and validate its existence. This applies not only to the history of a particular region, but also to such history as can be used to contradict the demarcation of "us."

The main aim of this paper is to examine how and to what extent the relatively new ad hoc regions in Czechia use history, historical and historicizing elements to present their image, and how they reinterpret them in order to foster a sense of territorial togetherness among their inhabitants. We are not only interested in the selected topics, elements, and historical periods, but also the chosen strategies of historical reinterpretation and how it is presented. The paper will specifically focus on Local Action Groups (LAGs) and we want to contribute to the ongoing discussion on the possibilities and methods of activating the (rural) regions' endogenous potentials for development. Our case study focuses on the local elites at the regional level who possess the power to create regional images and attempt to promote these images within the local community. Here, the bottom-up and topdown approaches interfere with each other. The regional actors poise the attraction of local attention (local temper, feelings, relations) on the one hand and the official regulations and politically superior national (and even international) narratives on the other. This may result in various approaches to the interpretation of history and therefore in various histories.

\section{Methodological remarks}

Local Action Groups (LAGs) are relatively new institutions in the Czech environment. They represent a very dynamic (not yet stabilized) element in the Czech regional system. In Czechia, these regions began to be formed 
in 2002 in connection with the country's preparations to join the European Union. Since municipalities of more than 25,000 inhabitants cannot be part of a LAG, the LAGs represent a platform of predominantly rural regions. From the perspective of economic development, rural regions are disadvantaged compared to urban regions, and they are, thus, more forced to seek alternative strategies of development and try to activate their endogenous potential (JANČÁK, V. et al. 2008).

LAGs are based on the LEADER method of regional management and also on the principle of community-led local development, which creates the potential to strengthen the community's sense of togetherness, supports local social capital, and activates the territory's endogenous potential for development. It can therefore be assumed that LAGs need to link their authority with the inhabitants' regional consciousness, either by adopting an existing regional identity or constructing an entirely new one. Joining the historical development of a territory and its reinterpretation in order to strengthen the image of togetherness is one of the possible strategies to anchor the new regional initiatives within the regional system (SEMian, M. et al. 2016). Currently, there are 180 LAGs in Czechia. In total, more than 90 per cent of Czech municipalities are engaged in one of these LAGs.

LAGs, thus, represent a suitable subject with which to study the process of regional identity formation, or, in our case, the significance of history and historical elements, and their reinterpretation within this process. Moreover, this rich source of information has been used very little in similar studies to date. On the other hand, this sort of source of information is also limiting, which must be taken into consideration when interpreting the findings. The main limitations stem from the motivation behind the foundation of LAGs. Despite the previously mentioned significance of the regional initiatives, the pragmatic motivation of their foundation merely in order to have access to funds and receive subsidies cannot be overlooked. Such initiatives are ephemeral. They last only as long as funds can be divested, and cease when the subsidies run out. A further limitation can be the technocratic approach to the shared LAG information - in particular strategic documents - when the purpose of the documents more or less influences the language and the content of the analysed text. Finally, there is the influence of the national and supranational structures and frameworks that help run the institutions studied herein through terms, rules, and incentives.

The research itself had two phases. In the first phase, we evaluated the primary presentation of all 180 LAGs registered in the National Network of Local Action Groups in Czechia (NNLAG; Národní sít Místních akčních skupin České republiky) as of January 2017. The primary presentation of the region can be understood as the name, logo, and slogan of the individual LAGs (see Pike, A. 2011; KašKová, M. and Chromý, P. 2014). To this trio, we added the introductory picture - photograph - on the LAGs' websites, with the exception of photographs generated at random from a photo section. These pictures were included in the research because, next to the name and logo, it is the first information that a person sees when searching for the LAG. The introductory illustrations, thus, greatly influence one's first impression of the region in question. We evaluated the name of the LAGs through a motivational analysis. We then subjected the logo, slogan, and introductory pictorial presentation to a content analysis. In the case of LAGs that use historical and historicizing elements in their basic presentation, a greater level of historical reinterpretation in other official materials can be assumed. Therefore, based on the results of the first phase, we identified a total of 42 LAGs (see Figure 1), which we subjected to further analysis.

In the second phase of the research, we evaluated the official texts available on the websites of the selected LAGs. We focused specifically on the Strategy of CommunityLed Local Development (SCLLD; Strategie komunitně vedeného místního rozvoje); the journals, bulletins, and newsletters pub- 


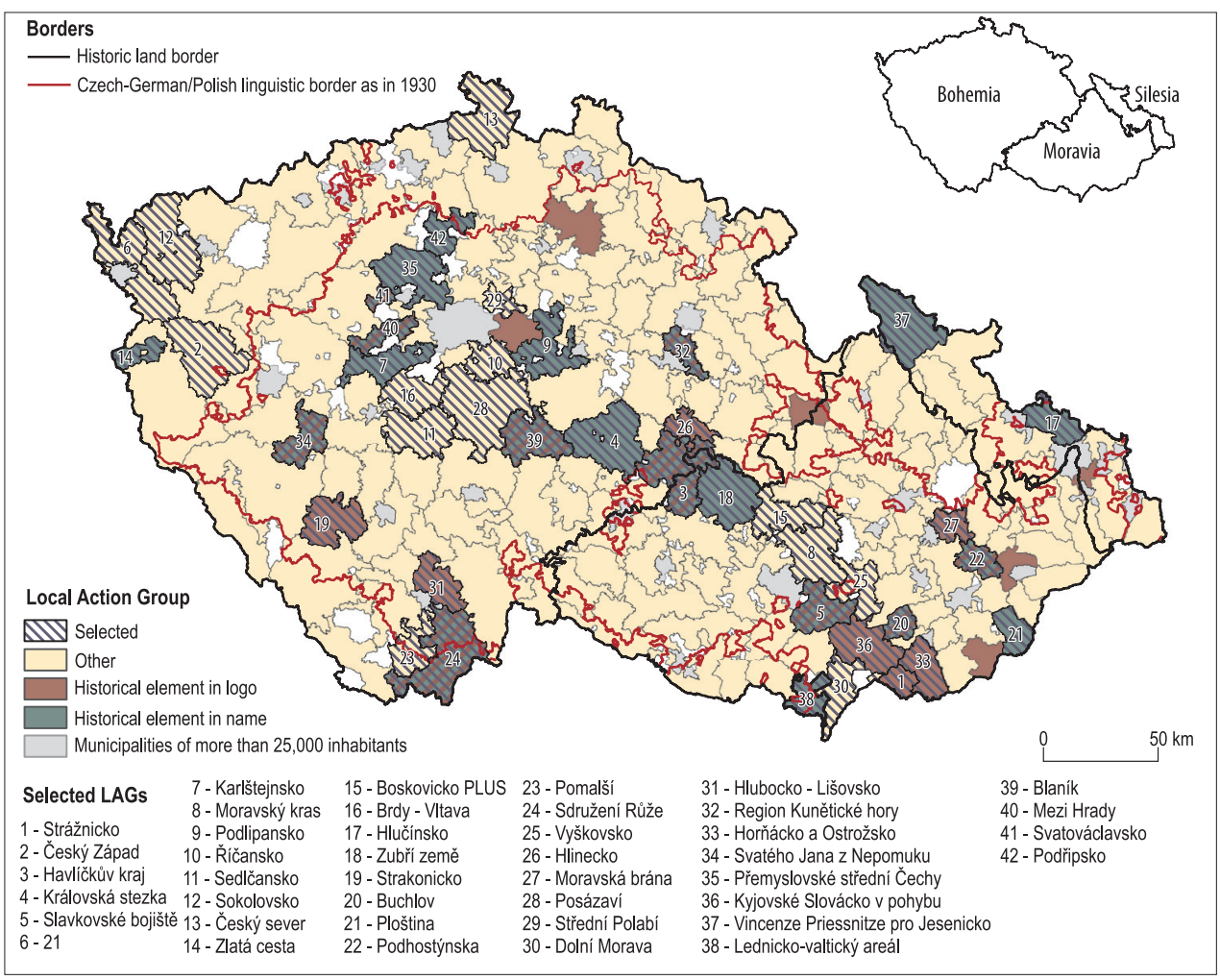

Fig 1. Historical elements in the names and logos of LAGs in Czechia, January 2017. (Compiled by SEMIAN, M.)

lished by LAGs; the promotional materials (most frequently flyers, informational panels on trails, publications, etc.); the popularizing texts about individual projects and their output; promotional texts about the social events organized or supported and presented by the individual LAGs. These sources of information represent the region's main tool of inward and outward communication. The SCLLD strategy is the region's current vision for development (for the period of 2014-2020), and it contains not only the situational analysis of the territory, but also the strategy for development and the implementation plan of this strategy.

The SCLLD strategy is, thus, how the regional actors view their own territory and its values - the vision of the direction that the region will take and the means with which it will achieve it. The point of the newsletters, etc. is, thus, to inform the territory's inhabitants not only about the LAG's activities, but also about the region itself. They are a means to create the internal image of the region and strengthen the feeling of regional togetherness. The promotional materials are then marketed outwardly to appeal to tourists and visitors, and contribute to the reproduction of the region's external image. Texts about projects and events are a source of information about the LAGs' specific activities and the region's social and everyday life. They reveal the specific strategies and tools of historical reinterpretation used by the LAGs' key actors. We conducted keyword searches in all of these texts to find passages referring 
to the region's history, traditions, heritage, or monuments. We then subjected them to a semantic analysis. We focused primarily on which of the region's historical topics and elements, historical periods and events are presented; how and for what purpose are they reinterpreted; and how they are presented to the public. During this research phase, we focused on the general as well as specific examples of using history and historical elements, and we tried to identify various communication strategies based on their reinterpretation.

\section{Historical and historicizing elements in the LAGs' primary presentation}

We must start by noting that, in general, the LAGs' presentations touch on history to a lesser degree (Table 1). More precisely, they use topics from history primarily in their materials as cultural-historical monuments. Usually, it does not go beyond the simple statement: "there are a lot of (important) cultural heritage sites in the region." This is mostly due to the continuing pragmatic approach to LAGs as a means to distribute money (repair monuments) and the economic motivation to commodify the territory's history, or rather its heritage, in the interest of tourism.

We managed to identify a total of 21 LAGs with historical names (see Figure 1; cf. SEMIAN, M. et al. 2016). In contrast to the previous research purely on regional names, we added the names of some newly created LAGs, but also the names of renamed current LAGs ${ }^{3}$. The historical motifs used in the names are most often based on the names of historical monuments or events (e.g. LAG Ploština,

\footnotetext{
${ }^{3}$ For example, the LAG Za humnama newly changed its name to LAG Slavkovské bojiště, based on a historical event, which, due to the significant monument to peace form the central historical and landscape landmark of the territory, in November 2014. The change was based on the recommendation of the Ministry of Agriculture that the name should better reflect the LAG's geographic location.
}

Table 1. The usage of historical elements in the selected aspects of LAGs in Czechia, January 2017.

\begin{tabular}{|c|c|c|c|c|}
\hline \multicolumn{4}{|c|}{ Historical element in } & \multirow[b]{2}{*}{$\underset{0}{\pi}$} \\
\hline 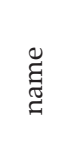 & $\begin{array}{l}0 \\
80 \\
0\end{array}$ & $\begin{array}{l}\tilde{D} \\
0.0 \\
\frac{0}{\omega}\end{array}$ & 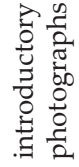 & \\
\hline 21 & 23 & 7 & 51 & 180 \\
\hline \multicolumn{5}{|c|}{ In per cent } \\
\hline 11.7 & 12.8 & 0.4 & 28.3 & 100.0 \\
\hline
\end{tabular}

* Source: Websites of individual LAGs.

LAG Karlštejnsko) and the names of historical figures (e.g. LAG Havlíčkův kraj, LAG Svatováclavsko), or the names of noble families (LAG Sdružení růže, LAG Zubří země). Names based on historical trails (LAG Zlatá cesta), and historical regions (LAG Hlučínsko), or mythological places (LAG Blaník) are rare. Based on the methodology selected, we did not include names based on cultural and ethnographic regions, despite their historicizing potential (see SEmian, M. et al. 2016).

A total of 23 LAGs have a logo that evokes history. Of these, only 10 LAGs have names based on history. In the logos, the stylized motif of the monument is used most often (12 times) (e.g. a castle, a manor, a monument, a pilgrimage church), or its silhouette, or its setting into a broader panorama of its landscape. In most cases, it is a specific building that is characteristic for the region in question (e.g. LAG Kunětické hory; see Figure 2).

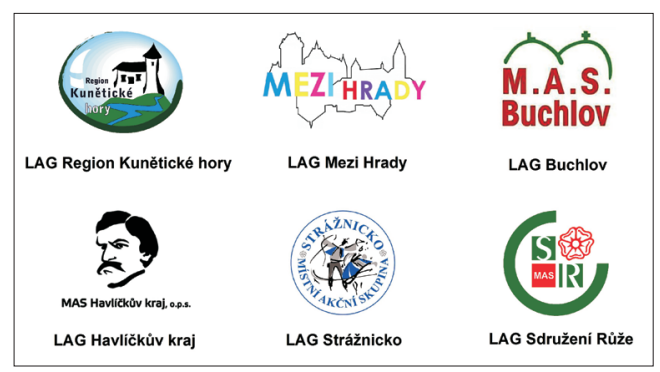

Fig. 2. Selected examples of LAGs' logos with historical elements 
The LAG Mezi hrady is a specific example. Its logo depicts a silhouette of three distinct castles, of which only one lies within the LAG's territory. Another specific example is LAG Buchlov, which uses the signs on tourist maps to symbolize two peaks with monuments. In several cases, the monument is not specified (e.g. LAG Region Pošembeří). Some other ways of creating the logo use elements of folklore that are typical for the territory in question (e.g. LAG Strážnicko), or the specific attributes tied most often to the name of the LAG (e.g. LAG Havlíčkův kraj $\left.{ }^{4}\right)$. The logo of LAG Sdružení růže is worth mentioning. It stylizes the coat of arms escutcheon, in which there is a white rose with a red core and outline in one field. The LAG refers to the Rožmberk family, which owned most of the LAG's territory in the past, in its other presentation. But the Rožmberks had a red rose in their coat of arms. A white rose on a red field (albeit with a gold core) is the coat of arms of the sibling-family of Landštejn and Třeboň, who owned only a small portion of the territory. This example shows how historical accuracy is sacrificed to the aesthetic aspect of the logo.

Together with the regional name and logo, a slogan is believed to be a key component of the regional branding process (KAšKoví, M. and Снгоми́, P. 2014). Thus, it may be used as a tool for regional promotion (PIKE, A. 2011). However, only a few LAGs have a slogan, and only seven base their slogan in history. The studied amount is so small that it cannot yield any general trends. But it is apparent that LAGs can work with historical topics in their slogan in various ways. They can be neutral - e.g. LAG Karlštejnsko - History and nature at your fingertips (Historie a príroda jako na dlani); LAG Kyjovské Slovácko v pohybu - Region of wine, monuments, and folk tradition (Region vina, památek a folklornich tradic), but they can also include ideology, or marketing - e.g. LAG Hlučínsko ${ }^{5}$ - We know where

\footnotetext{
${ }^{4}$ Depicting the head of Karel Havlíček Borovský.

${ }^{5}$ LAG Hlučínsko used the more explicit slogan in 2014: From the Prussian past to the European future (Od Pruské minulosti k Evropské budoucnosti).
}

we came from and where we are going (Vime odkud a kam jdeme); LAG Hlubocko-Lišovsko - The path to tradition leads through a modern region (Cesta $k$ tradicím vede moderním regionem), LAG Moravský kras - Enchantingly beautiful scenery, caves inhabited in ancient times and the history of "Bohemian and Moravian ironworks." All this is reflected in the work of the inhabitants and the products that deserve your attention (Čarokrásné krasové scenérie, pradávno obývané jeskyně a historie „železné huti českých i moravských zemí. To vše se odráži v práci zdejších obyvatel a výrobcích, které zasluhuji Vaši pozornost).

The last element of the region's primary presentation that we analysed are the introductory photographs on the LAGs' websites. These pictures are one of the first things one notices when looking at the sites. They, thus, have the potential to significantly influence the observer's first impression of the region (Photo 1).

The most common form is the landscape photograph, capturing the general landscape view of the countryside. Someone who knows the region can sometimes identify a specific place, mountain, town, or monument. In this type of presentation, roughly a fourth of the LAGs use a historical motif; the vast majority use a photograph of a specific monument, or its setting within the countryside. The second most common is the depiction of people in regional dress, most often during a celebration. In this case, there is usually not just one photograph; the vast majority uses a series of photographs that can be described as "life in the region". These series are supposed to evoke the region's rich social life, and showing people in regional dress underlines the emphasis on the territory's preservation of folklore traditions.

\section{Reinterpretation of history in the LAGs' presentation}

Based on the level of work with historical elements in the LAGs' primary presentation, we selected 42 (see Figure 1) that reflected 


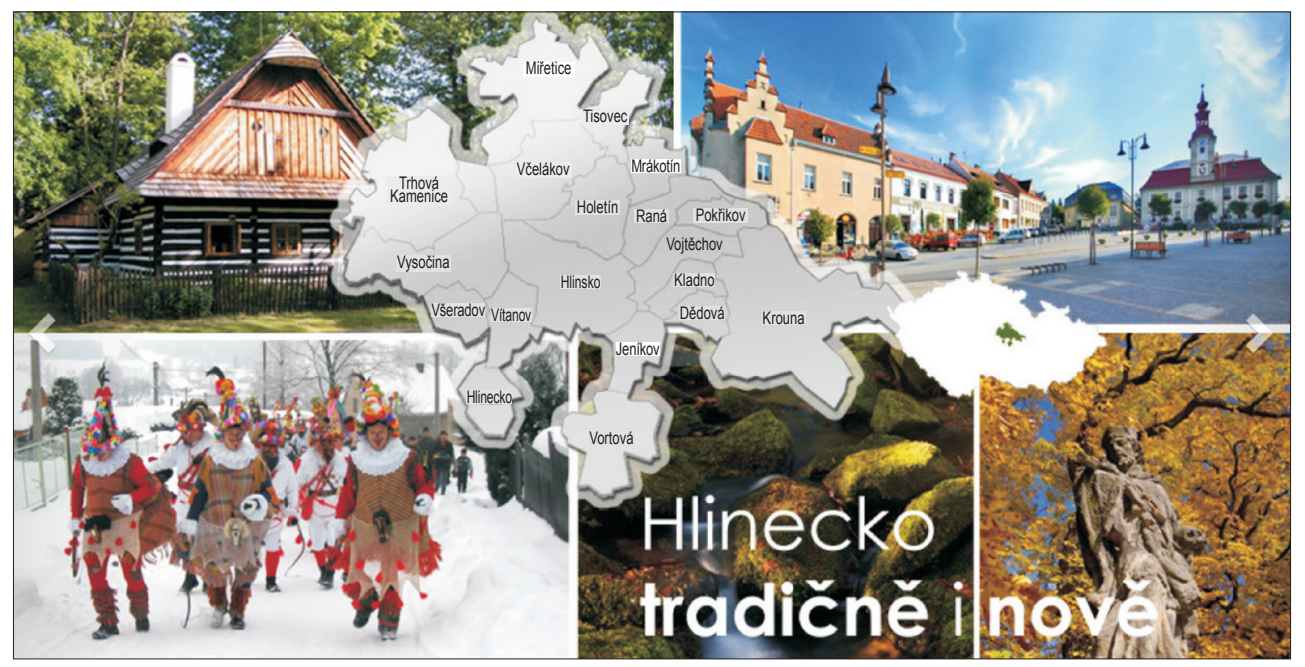

Photo 1. The example of introductory photographs depicting both folklore tradition and historical monument, LAG Hlinecko. Source: http://www.mashlinecko.cz/

historical or historicizing topics the most. We subjected the selected LAGs to intensive research on how they use history and its reinterpretation in official documents and LAG presentations. We managed to identify several general approaches that can be divided into four topics: monuments, tradition, identity, and historicizing events.

The most reflected topic infused with history is without a doubt cultural-historical monuments. As the repair of cultural-historical monuments is one of the supported activities planned for 2014-2020, it is a factor that influences the LAG's choice. Most LAGs include maintenance (repair, revitalization, renewal) of historical monuments, trails, etc. in their strategic documents as one of their priorities for development. This maintenance is defended by the need to protect the cultural heritage (without a more detailed specification of what such cultural heritage means) and especially in the case of monuments with supra-local significance, by the need to support tourism in the region. There is a whole list of promotional materials (books, brochures, flyers, panels on trails) on the monuments, primarily on their history.
The history of the individual villages in the region is similarly presented.

The LAGs use several different ways to deal with the traditions that represent another significant group of topics. First is the craft tradition and the traditional products it produces. Practically, all LAGs to a certain extent participate on the regional product brand's management (see KAšKová, M. and Chromý, P. 2014). Protecting the region's living heritage supports traditional crafts, but it also supports small businesses, however the question of their authenticity remains unanswered (cf. CoHen, E. 1988).

The LAGs often point out a tradition of economic production that can be the glue that connects the whole region. Specific agricultural activities (wine-making, fruit farming, etc.) are the most common. The second way in which the concept of tradition is understood is in the sense of folklore. This means various activities and events that are part of life in the village. The most common of these events is carnival, the harvest supper, harvesting grapes, etc. Here, too, the question of the authenticity of the traditions arises, because somewhere the traditions 
go far back into past uninterrupted ${ }^{6}$, and elsewhere these events are newly organized (renewed) in order to revitalize the region's social life and strengthen togetherness. In terms of the concept of tradition as folklore, regional dress is a specific element. Primarily in Moravia, they are a symbol of living traditions that have been maintained (e.g. LAG Horňácko and Ostrožsko, LAG Kyjovské Slovácko in motion).

The third topic that is typical for most of the assessed LAGs is the emphasis on the feeling of territorial togetherness and the territory's common history. The LAGs approach this problem from various angles. It is very common to use phrases such as "territory with a rich history", "territory with a long (deep) tradition", or "since time immemorial", and generally to underline "the long continuity of settlement in the area and historical togetherness" in strategic documents, but generally these statements do not explain what is meant by historical togetherness more specifically. Occasionally, some of the LAGs are more specific. For example, LAG Karlštejnsko refers to its territorial togetherness based on its position along the old medieval trade route from Prague to Nuremberg called "Via Carolina", which "had a major impact on the development and wealth of this area in old times" Nevertheless, some LAGs go even further back in history, stressing the presence of Celtic and prehistoric settlements without any links to the present state (e.g. LAG Buchlov).

A second type of approach is the emphasis on the need to educate the region's inhabitants (mostly school-aged children) in the local history and foster their positive relationship to the region, its history and, thus, encourage their feeling of regional togetherness. Various strategies can be found in this case. The most interesting are the various interac-

\footnotetext{
${ }^{6}$ In rare cases, this tradition is even registered in the UNESCO cultural heritage list; e.g. Carnival - LAG Hlinecko.

${ }^{7}$ Surprisingly, LAG Zlatá cesta refers to the same old trade route. They are using the same arguments of development and wealth brought by the route into the region, however, they call it "the Golden Route."
}

tive games for families with children, who need to visit predetermined places of interest in the territory and complete activities about them, stimulating interest in the local history. The games use various methods, including modern and popular ones such as geocaching, boardgames, interactive educational trails, competitions, etc. (e.g. LAG Střední Polabí, LAG Český sever). Other LAGs try to capture children's interest in their history through exchange trips with partner LAGs, or they support the publication of books not just about local history, but also legends, tales, and stories (e.g. LAG Hlinecko, LAG Ŕíčansko). Although one can argue about their authenticity as well as their genuine regional uniqueness and specificity, the collected stories grant tradition to the region.

This leads us to the specific topic of CzechGerman relationships. The history of this relationship is quite turbulent and to a certain extent can still be seen as a conflict, especially in the borderlands, where the German-speaking population was expelled after World War II (Kučera, Z. and Chromý, P. 2012). At a time when transnational cooperation is one of the priorities of the European Union, in extreme cases one may expect a revisionist, or, in part, a pandering approach to these events and the willful omission of the expulsion period from the region's history (VAŇKOvÁ, M. 2008). It is therefore perhaps surprising that many LAGs in the borderlands emphasize the post-war exchange of the population in their strategic documents (e.g. LAG Sdružení růže, LAG Sokolovsko). But they almost exclusively interpret this event in its relationship to the development of the number of people living in the territory and note that the population exchange had a negative impact on the inhabitants' territorial togetherness, which lasts to this day. In terms of Czech-German relationships, they are (if at all) interpreted as good neighbourhood (e.g. LAG Zlatá cesta), or they omit this question entirely.

The craft traditions and products made by the German speaking population are interpreted as Czech traditions based on territorial togetherness (e.g. LAG Český sever). 
Remembering wartime guilt and the atrocities that the Germans committed against the Czech population during World War II (and vice versa after World War II) is rare. An example may be LAG Hlinecko, or LAG Ploština, but they are close to the villages of Ležáky, or Ploština, which the German army burned down. Similarly, the period of Communist rule (1948-1989), except for a few exceptions, is never emphasized (e.g. LAG Karlštejnsko). This period in Czech history is still seen as highly contentious.

One of the most common types of historical reinterpretation for various purposes is the organization of events with historical themes, or at least with historicizing elements. We have mentioned many of these activities above (folklore traditions, craft markets, historical exhibits, lectures, trips, etc.). Another group are the mining celebrations that are increasing in popularity and almost all of the LAGs with locations historically connected to mining support them. Last but not least, we need to mention the various events and celebrations in period dress that often take place in castles, manors, folk museums, or historic towns and during various anniversaries. Although the selection of the period for the costumes is subject to outside influence (the history of the location, the cost of the costumes, etc.), certain periods are preferred over others. The most popular is late medieval - gothic - fashion, which is primarily connected to the culture of castles, jousting tournaments (Photo 2), and the founding of historic towns. In terms of the historic figures, the figure and period of the emperor Charles IV is currently in the prime of its popularity.

One can also see $19^{\text {th }}$ century both urban and rural costumes very often. These costumes can be seen at various markets and craft fairs, where they help promote and sell regional products their traditions often date back to this period (spa wafers, beer, etc.), or refer to rustic rural culture. With their connection to the industrial revolution, these costumes are used on historical train rides, or Czech national events (the National Revival period). Renaissance and baroque fashion is used to a lesser extent during castle celebrations. Military costumes are a special category. They are frequently used to reenact historical battles, mostly from the medieval period and jousting tournaments, the Thirty Years' War, the wars among the empires in the $18^{\text {th }}$ century, and World War I and World War II. These events are linked to the location of the specific battle, or fortification from World War II, and as an unrelated addition to larger celebrations.

In terms of space, most of the selected LAGs (the ones where the historical aspect is the strongest out of the aspects analysed) are concentrated in the hinterland of larger cities, especially the capital city of Prague, and in Southern Moravia (see Figure 1). These areas are historically the core areas of Czechia (see NováčEK, A. 2005). It is not then surprising that they have a greater concentration of important historical monuments or historical events. The reinterpretation of history in these LAGs can function as an advantage over the rest of the competition. Moreover, their position in the hinterland of large cities encourages the active presentation of the historical heritage in order to get the inhabitants of these cities to visit a region close by.

In LAGs in the Moravian ethnographic regions in particular one can observe a qualitatively different approach to the reinterpretation of history. Thanks to their specific histories (concentration of national revivalist activities in Prague, later industrialization, etc.), these regions are more traditionalist, conservative, with a greater level of religiosity, and so they base their identity mostly on a lived folklore tradition. In contrast, in Bohemia the folklore tradition is mostly a "museum piece". Also, the LAGs in the resettled borderlands in general work with history much less. This fact can be interpreted as the expression of the interrupted development of settlement, which can be seen today in the inhabitants' relationship with the territory. Other factors, such as the presentation of a mountainous and foothill landscape as the primary enticement for tourists, a lower number of important monuments, contribute to this situation. 


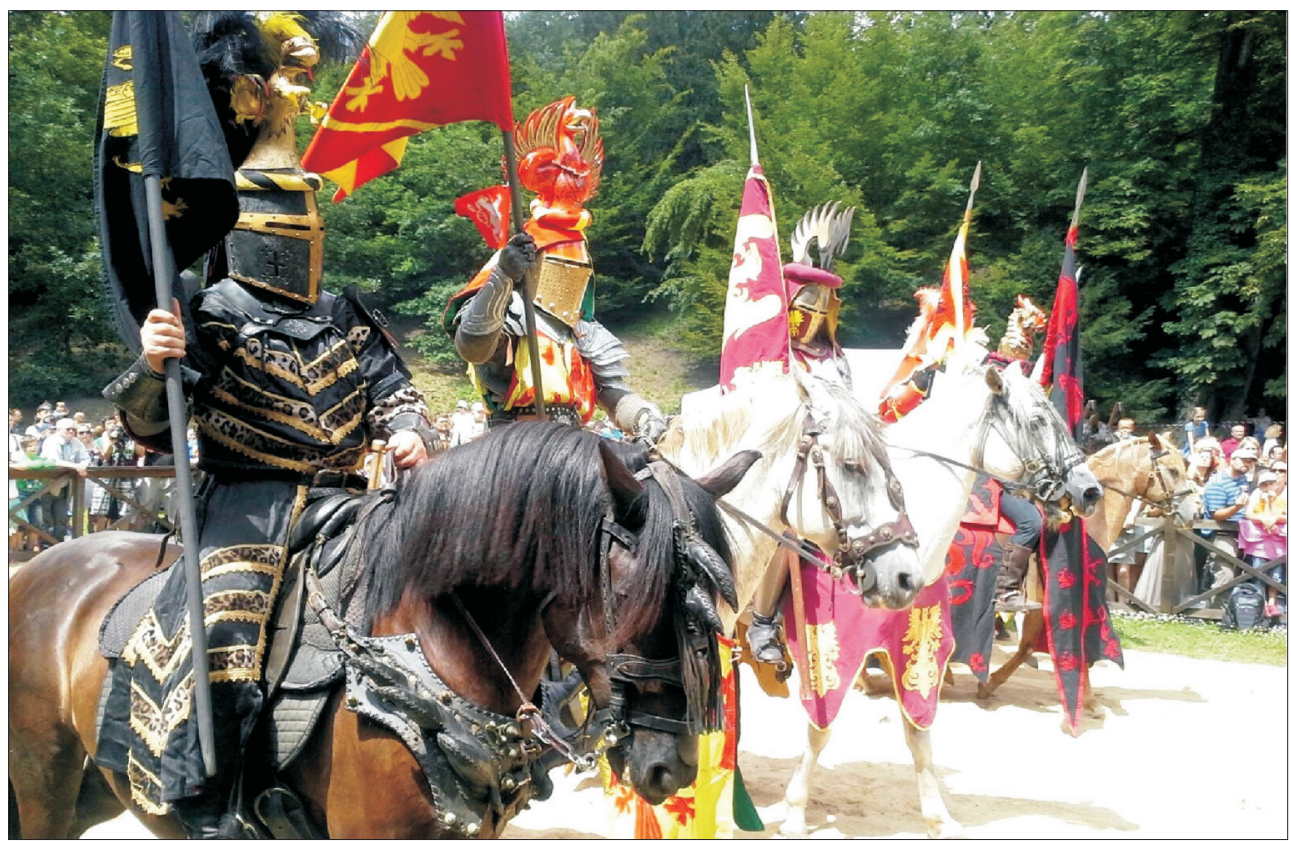

Photo 2. Historic costume is very common way of the commodification of history. (Photo by ŽIrovNICKÁ, K.)

Here, we would like to turn the attention from the commonly used strategies to several specific cases, where the reinterpretation of history is an important component of the LAG's communication strategy. In its presentation, LAG Hlučínsko refers to its peculiar history, which it defines as a "specific historical, cultural, and national development that has no equal in our state". The region's identity is significantly influenced by its position at the border, which changed state affiliation six times since the middle of the $18^{\text {th }}$ century. This history had an impact on its ethnic and linguistic makeup, which, despite the dramatic changes in the $19^{\text {th }}$ century, can still be seen today, including in its folk name "Prajzsko". LAG Hlučínsko used its specific dialect and the region's other characteristics (level of religiosity, inhabitants' feeling of togetherness) in its inward and outward presentation and used them to define itself against other regions. Its specific dialect and historical sign has even made it into the name of common investment projects, such as "From corvée to modern agriculture"; "Horse is past, tractor the future"(both acquisition of agricultural technology); "Really nice chapel at Dvořisko" (restoration of a small chapel $)^{8}$.

The phenomenon of historicizing promotional names can be seen in other LAGs. By using journalistic quirk and pop-cultural references, these names may transcend the limits of regional history, or can be used even without any relationship to the region, for example "How we worked the mill in Libuše's age" (article about old mills), "Four new musketeers have entered the King's Guard of the Pernstein region" (article about newly labelled regional products) ${ }^{9}$.

\footnotetext{
${ }^{8}$ In Czech: Od roboty k modernímu zemědělství; Kůn̆ je minulost, traktor to je budoucnost; Ganz fajna kaple na Dvořisku.

${ }^{9}$ In Czech: Jak se mlelo za Libuše (LAG Přemyslovské střední Čechy); Čtyři noví mušketýři vstoupili do královské gardy Kraje Pernštejnů (LAG Kunětické hory).
} 
The historical symbols can obtain such importance that they become a part of the complex communicational strategy of a region targeted to both its inhabitants as well as visitors, etc. The LAG Přemyslovské střední Čechy has based its communication on the mythology of national existence, as well as the historical presence of the first documented reigning Bohemian family. In their various materials, they use the names and elements of both mythological and historically documented persons and events. Moreover, the regional actors call themselves "Přemyslids", like the members of the Premyslid family. In their statements, they are aware of their local history, its values, and its limits; however, they use the historical importance of the territory to reclaim its importance in the national context. The regional consciousness and pride based on the understanding of local history has an important role in this reclaiming. Other LAGs, such as LAG Český sever, which presents itself in a complex way as the so-called Tolštejnský dominion (Tolštejnské panství), or LAG Sokolovsko, which, in its efforts to rid itself of the stigma of a rootless border region, aims to renew its pre-war traditions and cultural heritage, have a similar strategy, even if not as thorough.

\section{Conclusions}

In this paper we focused on how and to what extent is the reinterpretation of history used as a tool of communicational and developmental strategy of the still relatively new regions in the Czech regional system - Local Action Groups. Based on our analyses we can formulate several generalizing conclusions.

In general, LAGs work with history and historical themes only in a very limited extent, even when the historical or historicizing element made its way into the institution's name or logo. Nevertheless, some LAGs work actively with history, and for some it has even become the central strategy of communication with its inhabitants as well as its visitors. When LAGs reinterpret history, they usually emphasize the material aspect of history (cultural-historical monuments) its revitalization and commercialization. The commodification of history and the region's heritage is then used primarily for tourism. At the same time, the need to foster a sense of territorial togetherness among regional inhabitants by encouraging interest in regional history and its interpretation is often emphasized. These latter activities are then aimed primarily at the younger generation to try to lower the probability that they will leave the region in the future.

From a spatial perspective, one can discern that LAGs in the hinterland of large cities commodify their history and heritage more often. These regions are trying to attract city visitors and motivate them to visit. In contrast, peripheral regions, or regions with discontinuous settlement, are more inclined to emphasize local inhabitants' feeling of territorial togetherness. These regions, however, prefer other principles when constructing their regional identity; they emphasize the nature and landscape of their region. In general, Bohemia and Moravia approach historical and historicizing topics differently. In Bohemia, reinterpretation is aimed at consumers and conceived as a popular attraction and fun (fairs and celebration in historical costumes). In Moravia, especially in its southern part, there is a greater emphasis on folklore traditions and their presentation as an integral part of the region's living culture. In Moravia, there is also a greater interest in religious monuments. Historically, Moravia has been more religious and traditional than Bohemia.

Through its reinterpretation, history is very flexible and conforms to specific interests and goals. This is its weakness, but it also makes it a powerful tool (see e.g. BůžEK, V. 2003). In the past, the reinterpretation of history contributed several times to the creation of nations and states, and it provides similar "services" to the regions. In Czechia at this level, one can distinguish three basic approaches to the reinterpretation of history.

The first one can be called regional patriotism. It is generally uncritical of its own region, 
and its goal is to strengthen citizens' sense of regional togetherness and regional pride.

The second approach to the reinterpretation of history is more critical. It is critical of the past in its effort to rectify old wrongs and revise previous reinterpretations of history.

The third approach, which is strongly influenced by efforts to deepen transnational cooperation, is the conciliatory interpretation of history. It focuses on the positive aspects, and tries to steer away from contentious topics. If it broaches them at all, it simply states the facts.

It is difficult to define the precise factors that stand behind the applied approach to, and the level of historical reinterpretation in the region's activities.

First, the influence of the regional manager, or LAG chairman, cannot be overlooked. The incorporated strategies may become a subject to their own personal interests and preferences.

Second, the localization factor plays a significant role. While regions with attractive natural landscapes can use these as their trademark, regions in the hinterland of larger cities have similar attributes, and so they are in a constant struggle for recognition, their unique and strong image, attractive to locals as well as visitors. Regions that have historically been at the core of the nation can then capitalize on their rich history and many monuments. The presence of significant supra-regional monuments (also museums) in the region exerts a similar influence on territories, which encourages historicizing activities.

Third, continuous or dynamic character of settlement is also a significant factor. Regions with discontinuous settlement suffer from disruption to people's relationship to the region's history. On the other hand, the reinterpretation of the local living and lived traditional culture represent a potential for the fostering of territorial togetherness predominantly in regions with less dynamic of settlement development.

Fourth key factor is the primary reinterpretation of the "golden age" period of the local and national history. These periods are then reinterpreted primarily in terms of economic and cultural prosperity rather than in terms of Czech statehood (political, power prosperity), just as it had been in the past. This is because of the strong economic orientation of many activities as well as the potential contentiousness of an uncritical nationalist reading of history. It is evident that the actors steer clear of these topics, or reinterpret them in a more conciliatory and revisionist light.

For Czechia, the $20^{\text {th }}$ century was a permanent struggle over its identity. National identity was emphasized, while regional identity was sidelined. What was most important was the expression of "us" (Czechs, Czechoslovaks, labour force) and the line separating "us" from "the others" (Habsburgs, Germans, "western imperialists", Slovaks). But the new millennium ushered in a reversal, and the significance of the local and regional identity began to grow. This could potentially erode not the national identity as such, but its meaning. The erosion of nationalism means that there is no need to "push out Habsburgs, Germans, or Slovaks" (and in the future also Communists) and their heritage.

Today, the heritage is assessed as being present in the territory, and therefore it is "ours" regardless its (national) origin. Such construction of "us" is driven predominantly by economic motivations and, thus, brings new struggles into action - struggles over power, money, and attention. The same principle applies to the process of creating the identity of modern regions. The need for the expression of historical territorial togetherness is very important for newly established regions, often unrelated to the current state of its development. Regional history is, thus, chosen, generalized, and reinterpreted for the fulfilment of various (predominantly economic) goals.

Acknowledgements: The authors would like to thank to both reviewers for insightful comments. The article has been accomplished with financial support from the Czech Science Foundation (project P410/12/G113: 'Historical Geography Research Centre'). 


\section{REFERENCES}

BŮŽEK, V. 2003. Region v historickém diskurzu (Region in historical discourse). Jihočeský sborník historický 72. 5-13.

Cohen, E. 1988. Authenticity and commoditization in tourism. Annals of Tourism Research 15. (3): 371-386.

Crang, M.A. 1998. Cultural Geography. London, Routledge.

Giddens, A. 1991. Modernity and self-Identity: Self and Society in the Late Modern Age. Cambridge, Polity Press.

Jančák, V., Havlíčé, T., Chromý, P. and Marada, M. 2008. Regional differentiation of selected conditions for the development of human and social capital in Czechia. Geografie 113. (3): 269-284.

KAšKová, M. and Chromý, P. 2014. Regional product labelling as part of the region formation process: The case of Czechia. AUC Geographica 49. (2): 87-98.

Keating, M. 1998. The New Regionalism in Western Europe: Territorial Restructuring and Political Change. Northampton, Edward Elgar Publishing.

KučerA, Z. and Chromý, P. 2012. Depopulation, resettlement and landscape changes in the peripheries of the Czech borderland. In The Political Ecology of Depopulation: Inequality, Landscape, and People. Eds.: Paniagua, Á., Bryant, R. and Kizos, T., Zaragoza, Rolde Foundation, CEDDAR, 191-213.

Kučera, Z., Kuldová, S. and Chromý, P. 2008. Heritage in landscape or landscape as heritage: The case of landscape change management in protected and development areas in Czechia. Europa XXI 17.87-96.

Massey, D. and Jess, P. eds.1995. A Place in the World? Oxford, Open University.

NovÁčEK, A. 2005. Dlouhodobé trendy polarizace prostoru v Česku v zrcadle populačního vývoje (Long-term trends of space polarization in Czechia in the mirror of population development). Historická geografie 33. 367-396.

PAAsI, A. 1986. The institutionalization of regions: A theoretical framework for understanding the emergence of regions and the constitution of regional identity. Fennia 164. (1): 105-146.
PAasi, A. 2013. Regional planning and the mobilization of 'regional identity': From bounded spaces to relational complexity. Regional Studies 47. (8): 1206-1219.

Pike, A. ed. 2011. Brands and Branding Geographies. Cheltenham, Edward Elgar.

Riukulehto, S. 2015. Regional history between time and space. In Between Time and Space. Ed.: Riukulehto, S., Newcastle upon Tyne, Cambridge Scholar Publishing, 1-21.

SEMIAN, M. 2012. Searching for the territorial shape of a region in regional consciousness: The Český ráj (Bohemian Paradise), Czech Republic. Moravian Geographical Reports 20. (2): 25-35.

Semian, M. 2016a. Region in its complexity: A discussion on constructivist approaches. Acta Universitatis Carolinae Geographica 51. (2): 179-188.

Semian, M. 2016b. Regions through Time and Space: Problem of Regionalisation. PhD thesis. Praha, Univerzita Karlova.

Semian, M., Chromý, P. and Kučera, Z. 2016. Name as a regional brand: The case of Local Action Groups in Czechia. Journal of Language and Politics 15. (6): 768-789.

Šubrt, J. and Vinopal, J. et al. 2013. Historické vědomí obyvatel České republiky perspektivou sociologického výzkumu (Historical consciousness of the population in the Czech Republic from the perspective of sociological research). Praha, Karolinum.

Tomaney, J. and WARD, N. 2000. England and the new regionalism. Regional Studies 34. (5): 471-478.

Tosh, J. 2015. The Pursuit of History: Aims, Methods and New Directions in the Study of History. $6^{\text {th }}$ edition. New York, Routledge.

VAŇKová, M. 2008. Konstruování a reprezentace "regionu": krajinou podstávkových domů (Construction and representation of a "region": Through the landscape of half-timbered houses). Biograf 45. 1-19. Online: http://www.biograf.org/ clanek.php?id=624 
